\title{
STOMATITIS APTHOSA REKUREN (SAR) MINOR MULTIPLE PRE MENSTRUASI (Laporan Kasus)
}

\author{
Amelia Thantawi* ${ }^{\star}$ Khairiati*, Mela Meri Nova*, Sri Marlisa*, Abu Bakar ${ }^{\star *}$
}

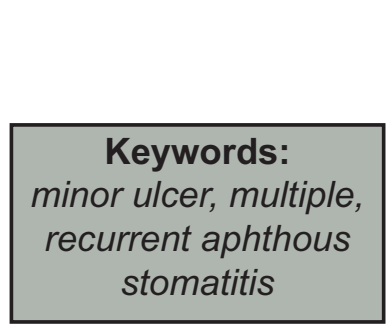

\section{ABSTRACT}

Recurrent aphthous stomatitis (RAS) is an inflammation of the soft tissues of the mouth that is characterized by recurrent ulcers. SAR is clinically divided into three types, ie recurrent aphthous stomatitis minor, major and herpetiform. Clinical features of minor types usually with a diameter of about 2-4 mm with yellow-gray base and surrounded by an erythematous halo, affects mainly the non-keratinized mobile mucosae such as lips and tongue, a few ulcers (1-5) or multiple at a time, minor ulcers usually heal within 10-14 days without scarring. Early lesions on the SAR is usually felt by people as burning, followed by extremely pain. The aetiology of RAS is unknown, but associated with a variety of predisposing such as menstrual cycle and trauma. Case management is topical steroids, topical antiseptic and vitamins $C$ to relieve the symptoms and fasten healing.

\section{PENDAHULUAN}

Rongga

mulut

mencerminkan kesehatan tubuh seseorang karena merupakan pintu pertama masuknya bahan makanan untuk kebutuhan pertumbuhan dan kesehatan yang optimal. Berbagai macam lesi sering kali terjadi di rongga mulut yang dapat disebabkan berbagai faktor, salah satunya adalah stomatitis aphtosa rekuren.

Stomatitis apthosa rekuren (SAR) juga dikenal dengan nama aphthae / canker sores / reccurent aphthous ulcerations (RAU) $)^{1,2,3}$. SAR merupakan suatu peradangan jaringan lunak mulut yang yang ditandai oleh ulkus yang rekuren tanpa disertai gejala penyakit lain ${ }^{2,4}$.

Lesi dini pada SAR biasanya dirasakan oleh penderita sebagai rasa terbakar. Kemudian bila telah terbentuk luka, rasa sakit semakin hebat. Kadangkadang dilaporkan adanya gejala-gejala pendahulu/prodromal seperti parestesia dan hiperestesia ${ }^{2,5,6}$. Rasa sakit dan ketidaknyamanan yang eksaserbasi dengan adanya pergerakan di sekitar ulser, seperti kegiatan makan, berbicara dan menelan ${ }^{5}$.
Karakteristik SAR biasanya berupa ulser rekuren dengan bentuk bulat atau oval dan pinggir yang dikelilingi eritematous dengan dasar lesi berwarna kuning-kelabu. Lesi terjadi dimulai pada usia muda, yaitu anak-anak dan masa pubertas, dan dapat terjadi pada orang dewasa. Ulser berlangsung selama 1 minggu atau bulan. SAR secara klinis dibagi menjadi 3 tipe, yaitu stomatitis apthosa rekuren minor, mayor dan herpetiformis. Gambaran klinis tipe minor adalah berukuran 2-4 $\mathrm{mm}$ atau kurang dari $1 \mathrm{~cm}$, simetris, dapat dimulai dengan munculnya makula eritematous yang berhubungan dengan gejala prodromal. Dasar ulser berwarna kuning-kelabu dan dikelilingi daerah eritematous pada mukosa bergerak dan tidak berkeratin seperti mukosa labial, mukosa bukal, dasar mulut, sulkus lingualis, dorsum lidah ataupun ventral lidah. Jumlah ulser dapat tunggal atau multiple, interval rekurensi 1-4 bulan. Tipe minor sembuh dalam waktu 10-14 hari tanpa meninggalkan jaringan parut ${ }^{1,3,4,5,6,7,8}$.

Etiologi SAR tidak diketahui, tetapi berhubungan dengan berbagai faktor

\footnotetext{
* Program Pendidikan Dokter Gigi Fakultas Kedokteran Gigi Universitas Baiturrahmah ** Departemen IImu Penyakit Mulut Fakultas Kedokteran Gigi Universitas Baiturrahmah

Korespondesi: ameliathantawi@gmail.com
} 
predisposisi seperti riwayat SAR dalam keluarga, trauma, siklus menstruasi, kehamilan, stres, alergi makanan, anemia, faktor imunologi dan defisiensi haematinik (defisiensi $\mathrm{Fe}$, asam folat dan vitamin B12) $)^{1,2,5,7}$.

Stomatitis apthosa rekuren(SAR) paling sedikit terjadi $10 \%$ dari jumlah populasi, dan prevalensi tertinggi mencapai $25 \%$ yang banyak terjadi pada individu yang bukan perokok. RAS banyak terjadi pada negara berkembang ${ }^{3,8}$. Sebagian besar pasien menderita stomatitis apthosa rekuren minor sebanyak $80 \%^{1,9}$.

Laporan kasus ini menggambarkan stomatitis apthosa rekuren minor yang terjadi secara multiple, dan diduga terjadi akibat faktor predisposisi dari siklus menstruasi dan trauma. Selain itu juga akan dijelaskan mengenai penatalaksanaan kasus.

\section{LAPORAN KASUS}

Seorang pasien berusia 37 tahun datang ke RSGMP Baiturrahmah dengan keluhan rasa sakit pada tepi kanan dan kiri lidah serta bibir atas bagian dalam sejak 4 hari yang lalu. Dari anamnesa pasien mengatakan terjadi perubahan bentuk, warna dan ukuran dimana dari hari ke hari sariawan semakin besar dan diawali dengan warna merah yang kemudian berubah menjadi kuning dengan dikelilingi warna merah. Sariawan tiba-tiba muncul diawali dengan rasa yang tidak nyaman seperti kesemutan yang sering muncul saat bangun tidur di pagi hari, kemudian merasa demam dan tidak enak badan. Pasien mengatakan sariawan dan demam yang dideritanya belum diobati. Jika pasien minum minuman dingin rasa sakitnya berkurang, namun rasa sakit bertambah hebat apabila pasien melakukan gerakan pada mulutnya seperti berbicara dan makan terutama makan makanan pedas. Dari anamnesa juga diketahui bahwa sariawan sering muncul menjelang terjadinya haid dengan jarak kekambuhan sekitar 1-3 bulan dalam 3 tahun terakhir.
Selain itu, pasien jarang mengkonsumsi sayur dan buah-buahan.

Pemeriksaan ekstra oral diketahui adanya kelenjar submandibula yang teraba dan sakit saat palpasi. Pemeriksaan Intra oral diketahui terdapat empat lesi, yaitu tiga lesi pada lateral kanan-kiri lidah dengan ukuran 2-4 mm dan satu lesi lainnya pada mukosa labial atas dengan bentuk bulat dan lonjong, warna dasar lesi kuning yang dikelilingi daerah eritematous (Gambar 1, 2, 3). Selain itu, oral hygiene pasien sedang, terdapat radik pada regio 15 dan 17 , karies pada regio 26, 47 dan 48. Beberapa gigi mengalami malposisi yaitu pada regio 12 , 22 dan 28 palatoversi, regio 23 labioversi, 31 mesiolinguoversi, 44 linguoversi serta regio 45 distobukoversi dan ekstrusi. Dari hasil pemeriksaan subjektif dan objektif, diagnosa yang dapat ditegakkan dari kasus adalah SAR minor multiple.

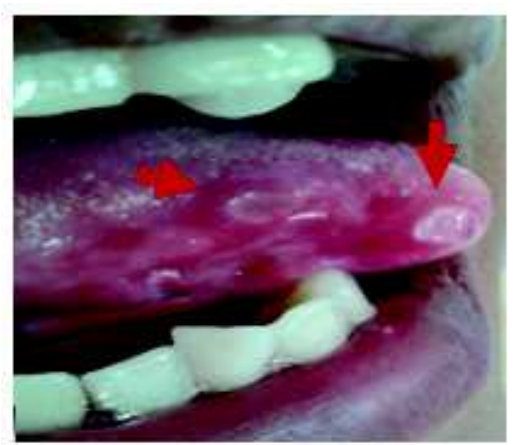

Gambar 1. Ulser pada lateral kanan lidah (kunjungan pertama)

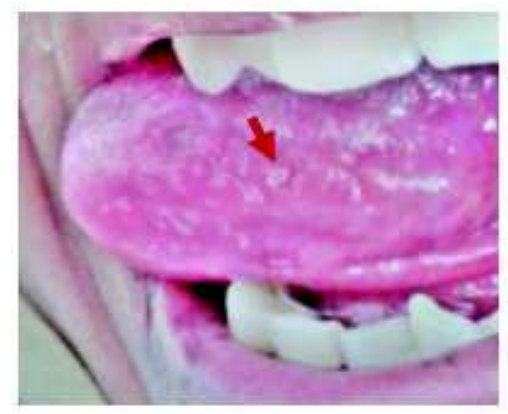

Gambar 2. Ulser pada lateral kiri lidah (kunjungan pertama) 


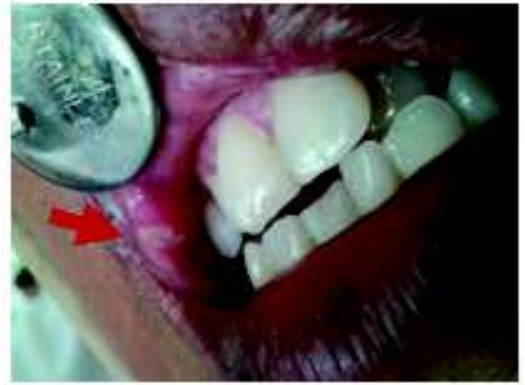

Gambar

3. Ulser pada mukosa (kunjungan pertama)

\section{PENATALAKSANAAN KASUS Kunjungan I (2 Oktober2014)}

Terapi dengan pemberian steroid topikal dan antiseptik topikal. Steroid topikal yang diberikan adalah Kenalog in Orabase yang berfungsi sebagai antiinflamasi dan mengurangi rasa sakit. Obat diaplikasikan 2-3 kali sehari di tempat yang terasa sakit pada waktu setelah makan dan malam hari sebelum tidur agar obat dapat berkontak secara optimal dengan cara dioleskan tipis pada lesi ${ }^{3,4,8,10}$. Pemberian antiseptik topikal berupa betadine kumur yang mengandung providone iodine. Providone iodine berfungsi sebagai bakterisida, serta dapat menjaga kebersihan mulut ${ }^{11,12}$

Selain obat-obatan di atas dapat juga diberikan penjelasan mengenai DHE untuk informasi mengenai penyakit yang dialami pasien yaitu SAR agar pasien mengerti dan mengetahui gejala dan penatalaksanaan yang tepat. Pasien dianjurkan untuk menjaga kebersihan gigi dan mulut. Selain itu, mengkonsumsi sayur dan buah-buahan secara rutin untuk mempercepat proses penyembuhan.

\section{Kunjungan II (10 Oktober 2014)}

Satu minggu kemudian pasien datang untuk kontrol pertama. Pemeriksaan intra oral diketahui jumlah lesi berkurang dan mengalami penyembuhan, hanya terdapat 2 lesi pada lateral lidah dan lesi pada mukosa labial mengalami penyembuhan (Gambar 4, 5,6). Kemudian kembali dilakukan pemberian kenalog in orabase dan vitamin C. Pemberian vitamin C
500 mg sebanyak 10 tablet diminum 1 kali sehari setelah makan. Vitamin C berfungsi untuk pembentukan kolagen yang berperan dalam penyembuhan luka, meningkatkan daya tahan tubuh, dan meningkatkan absorpsi serta metabolisme $\mathrm{Fe}^{13,14}$. Selain itu, pasien diintruksikan agar tetap menjaga kebersihan rongga mulut dan mengkonsumsi sayur dan buah secara rutin.

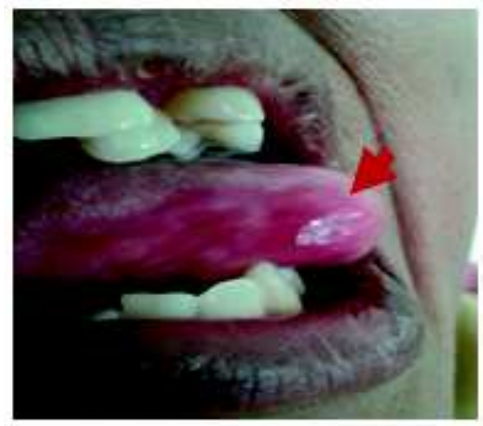

Gambar 4. Hanya terdapat satu ulser pada latera kanan lidah pasien

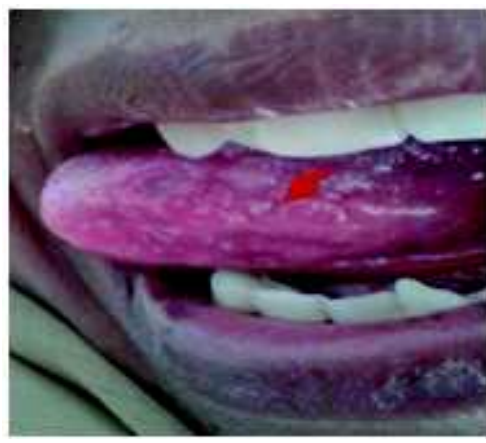

Gambar 5. Ukuran ulser semakin berkurang pada lateral kiri lidah

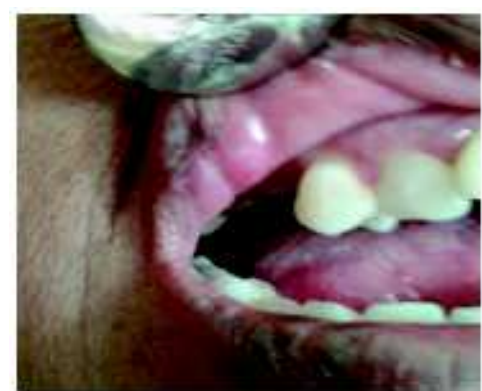

Gambar 6. Ulser mengalami penyembuhan pada mukosa labial 


\section{Kunjungan III (16 Oktober 2014)}

Kunjungan ketiga, kontrol dilakukan kembali pada satu minggu setelah kunjungan kedua. Dari hasil pemeriksaan intra oral diketahui semua lesi yang terdapat pada mukosa labial dan lateral lidah telah mengalami penyembuhan (Gambar 7, 8, 9).

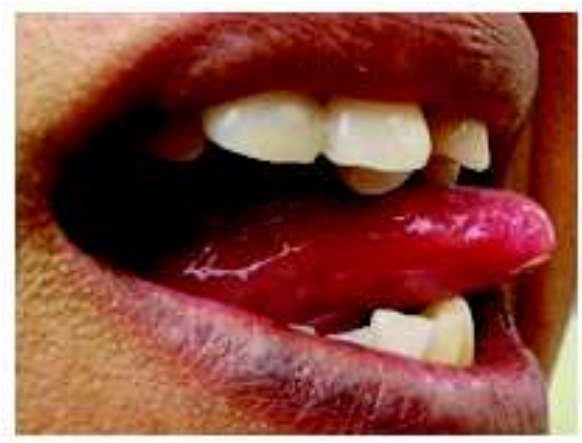

Gambar 7. Ulser telah mengalami penyembuhan pada lateral kanan lidah

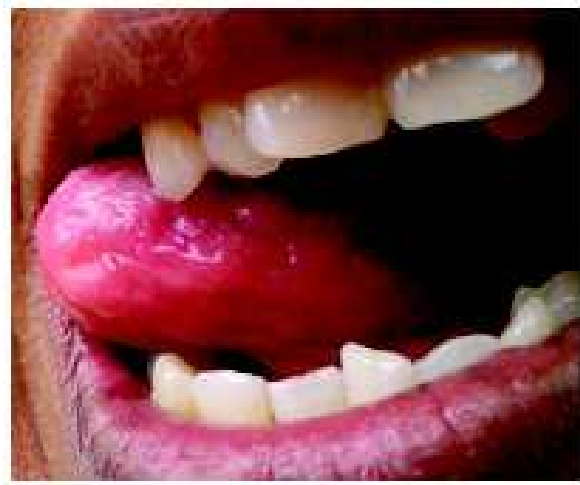

Gambar 8. Ulser telah mengalami penyembuhan pada lateral kiri lidah

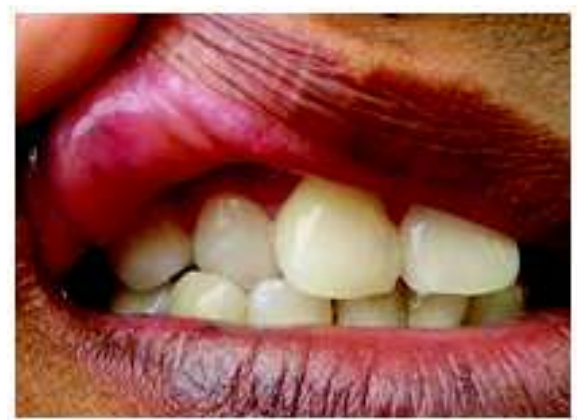

Gambar 9. Ulser telah mengalami penyembuhan pada mukosa labial

\section{Kunjungan IV (3 November 2014)}

Satu bulan setelah kunjungan ketiga pasien datang kembali dengan keluhan sariawan yang muncul kembali pada lokasi yang berbeda dan sama dengan sebelumnya. Anamnesa diketahui sariawan sering muncul menjelang menstruasi dan diketahui pasien dalam waktu dekat akan mengalami haid. Pemeriksaan intra oral diketahui terdapat ulser pada lateral kanan lidah, ujung lidah dan mukosa labial bawah (Gambar 10, 11, 12) Selain itu beberapa gigi pada rahang atas dan bawah pasien berjejal dengan bentuk cusp gigi yang tajam.

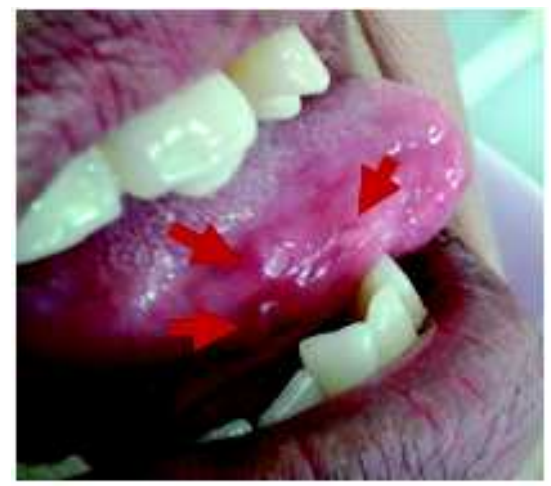

Gambar 10. Ulser kembali terjadi pada lateral kanan lidah

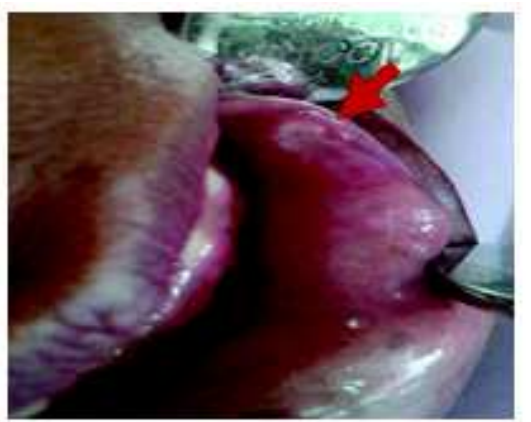

Gambar 11. Ulser terjadi pada mukosa labial bawah

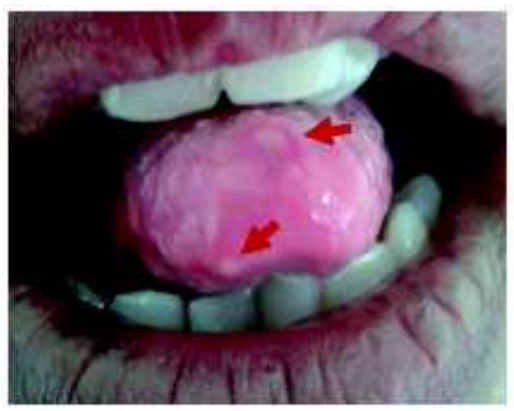

Gambar 12. Ulser terjadi pada ujung lidah 


\section{DISKUSI}

Diagnosis pasti SAR tidak ditegakkan melalui pemeriksaan laboratorium, tetapi berdasarkan riwayat dan gambaran klinis pada kasus. Biopsi jarang diindikasikan, biasanya hanya dibutuhkan untuk mengeliminasi diagnosa banding yang dicurigai dan tidak untuk mendapatkan diagnosis pasti. Bagaimanapun, untuk menghilangkan dugaan adanya gangguan sistemik dapat dilakukan pemeriksaan seperti pemeriksaan darah dan serum ${ }^{1,3}$.

Beberapa kriteria SAR minor multiple yang sesuai dari kasus adalah jumlah ulser bisa satu hingga lima atau multiple, ulser dangkal pada mukosa bergerak dan tidak berkeratin, pada kasus di mukosa labial dan lingual. Ulser berbentuk bulat dan lonjong dengan diameter tidak lebih dari $1 \mathrm{~cm}$ yang dikelilingi daerah eritematous, dasar ulkus kuning-kelabu, interval terjadinya rekurensi sekitar 1-4 bulan, adanya rasa sakit yang eksaserbasi dengan adanya pergerakan di sekitar ulser. Semua ulser sembuh spontan tanpa meninggalkan jaringan parut. Selain itu dapat terjadi infeksi sekunder ditandai dengan timbulnya limfadenopati. Nodus limfatik servikal dapat membesar dan adanya nyeri tekan ${ }^{3,5,7}$.

Dari anamnesa, munculnya sariawan sering terjadi pada waktu dekat menjelang haid. Hal ini diduga sebagai akibat dari beberapa faktor predisposisi SAR, yaitu siklus menstruasi atau faktor estrogen yang terjadi pada pasien dan trauma dari bentuk cusp gigi yang tajam serta malposisi gigi ${ }^{3}$. Hal ini diketahui dari pemeriksaan intra oral pada regio 12, 22 dan 28 palatoversi, regio 23 labioversi, 31 mesiolinguoversi, 44 linguoversi serta regio 45 distobukoversi dan ekstrusi. Oleh karena itu pasien tersebut memerlukan perawatan orthodonti untuk mengurangi frekuensi terjadinya SAR.

Perubahan kadar estrogen berperan dalam siklus menstruasi. Pada fase luteal terjadi penurunan kadar progesteron dalam siklus menstruasi ${ }^{3,15}$. Kadar estrogen dan progesteron turun drastis pada sekitar hari ke-28 ketika terjadi menstruasi. Fase luteal terjadi dalam waktu dekat menjelang menstruasi atau 14 hari setelah ovulasi dimana siklus menstruasi biasanya terjadi selama 28 hari ${ }^{16}$. Croley dan Miers meneliti pengaruh estrogen yang ternyata merangsang maturasi lengkap sel epitel mukosa mulut. Hasil penelitian Soetiarto dkk. menunjukkan bahwa rendahnya kadar progesteron dari normal beresiko tinggi terjadinya SAR. Pada penderita RAS yang disebabkan kadar progesteron yang rendah maka efek self limiting process berkurang, polimorphonuclear leucocytes menurun, permeabilitas vaskuler menurun sehingga mudah terbentuknya SAR yang muncul secara periodik sesuai siklus menstruasi ${ }^{17}$.

Penatalaksanaan RAS adalah mengatasi atau menghilangkan faktor predisposisi dan medikasi topikal seperti steroid topikal dan antiseptik topikal untuk menghilangkan gejala, selain itu juga dapat diberikan vitamin C3. Steroid topikal yang diberikan adalah Kenalog in Orabase. Kenalog mengandung Triamcinolone acetonide, yaitu kortikosteroid sintetik yang memiliki efek anti inflamasi, anti gatal, dan anti alergi. Kenalog merupakan steroid topikal yang berfungsi sebagai antiinflamasi yaitu meredakan peradangan yang berhubungan dengan lesi inflamasi dan lesi ulseratif oral, serta covering agent yang terdapat pada kenalog, yaitu orabase yang dapat mengurangi rasa sakit ${ }^{3,4,8,10}$. Pemberian antiseptik topikal berupa betadin kumur yang mengandung providone iodine. Providone iodine berfungsi sebagai bakterisida dan dapat menjaga kebersihan mulut ${ }^{11,12}$.

Pemberian vitamin C secara oral berfungsi dalam pembentukan kolagen. Kolagen merupakan senyawa protein yang mempengaruhi integritas struktur di semua jaringan ikat sehingga berperan dalam penyembuhan luka. Selain itu, mencegah infeksi karena dapat 
meningkatkan daya tahan tubuh terhadap infeksi, dan meningkatkan absorpsi serta metabolisme Fe. Vitamin $\mathrm{C}$ pada umumnya terdapat dalam sayur dan buah-buahan ${ }^{13,14}$. Kekurangan vitamin $\mathrm{C}$ mengakibatkan jaringan di mukosa mulut dan jaringan penghubung antara gusi dan gigi mudah robek yang akhirnya dapat menimbulkan sariawan ${ }^{18}$.

\section{KESIMPULAN}

Stomatitis apthosa rekuren dapat ditemukan multiple. Etiologi yang pasti tidak diketahui namun, banyak faktor yang mempengaruhinya. Pada kasus ini SAR terjadi pada saat siklus mentruasi dan adanya trauma akibat maloklusi. SAR minor dapat sembuh dalam beberapa minggu dengan menghindari atau mengatasi faktor predisposisi, medikasi, menganjurkan pasien untuk menjaga asupan gizi dengan baik serta menjaga kebersihan dan kesehatan mulut.

\section{DAFTAR PUSTAKA}

1. Neville, B.W., Douglas D.D., Carl M.A., Jerry E.B. 2012. Oral and Maxillofacial Pathology. 3th Ed. Elsevier. Hal: 331-6.

2. Pindborg, J.J. 2009. Atlas Penyakit Mukosa Mulut. Binarupa Aksara. Hal: 180-2.

3. Scully, C. 2012. Oral and Maxillofacial Medicine. 2nd Ed. Elsevier. Hal: 151-6.

4. Usri, K., dkk. 2013. Diagnosis dan Terapi. Edisi ke-2. LSKI. Hal: 59-60.

5. Birnbaum, W., Stephen MD. 2010. Oral Diagnosis: The Clinician's Guide. Editor: Lilian Juwono. Diagnosis Kelainan dalam Mulut, Petunjuk bagi Klinisi. EGC. Jakarta. Hal: 2712.

6. Langlais, R.P., Craig S.M., Jill S.N. 2009. Color Atlas of Common Oral Diseases. 4th Ed. Lippincott Williams \& Wilkins.

7. Coulthard, P., Keith H., Philip S., Elizabeth T. 2013. Oral and Maxillofacial Surgery, Radiology, Pathology and Oral Medicine. Vol.1. 3th Ed. Elsevier. Hal: 241-3.

8. Scully, C., R.A. Cawson. 2012. Atlas Bantu Kedokteran Gigi : Penyakit Mulut. Hipokrates. Jakarta. Hal: 25-6.

9. Hernawati, Sri. Mekanisme Seluler dan Molekular Stres Terhadap Terjadinya Rekuren Aptosa Stomatitis. 2014. Jurnal PDGI. Vol.63. No.1. Hal: 36-9.

10. Kasim, F,. dkk. 2010. ISO Indonesia. Vol. 45-
2010 s/d 2011. ISFI Penerbitan. Hal: 378.

11. Apriasari, M.L., Bagus S., Hening T.H. Sensitivity difference of Streptoccocus viridans on $30 \%$ Piper betle linn extract and 10\% providone iodine towards reccurent apthous stomatitis. 2011.

12. Nailullatifah, M., Diyah F., Ade I.A.K. Arlina N. Efektivitas Obat Kmur Proporlis, Klorheksidin dan Providone lodine Terhadap Indeks Plak. Medali Journal. 2013. Vol.1. No.1 Hal:18.

13. Almatsier, S. 2002. Prinsip Dasar IImu Gizi. Gramedia Pustaka Utama. Hal: 187-9.

14. Sroda, S. 2006. Nutrition for a Healthy Mouth. Lippincott Williams \& Wilkins. Hal: 66.

15. Ostrzenski, Adam. 2002. Gynecology: Integrating Conventional, Complementary, and Natural Alternative Therapy. Lippincott Williams and Wilkins. Philadelphia. Hal:24.

16. Benson, R.C. and Martin L.P. 2009. Buku Saku Obstetri \& Ginekologi. Edisi 9. EGC. Hal:47.

17. Soetiarto, F., Anna M., Sri U. Hubungan Antara Reccurent Aphthae Stomatitis dan Kadar Hormon Reproduksi Wanita. Bul. Penelit. Kesehat. 2009. Vol 37. No 2. Hal: 79-86.

18. Mojabi,F.B., Faezeh,M., Marjan,N., Pantea,N., Hassan,J. 2014. Therapeutic Effect Of "Iboprofen Diphenhydramine and Aluminium Mgs" On Recurrent Aphtous Stomatitis: A Randomized Controlled Trial. Journal Of Dentistry. Tehran University Of Medica Sciences. Iran. Vol.11. No.2. 